\title{
UJI EFEKTIVITAS EKSTRAK RIMPANG KUNYIT PUTIH (Curcuma zedoaria) TERHADAP PERTUMBUHAN JAMUR (Pityrosporum ovale) dan (Microsporum canis)
}

\author{
Lexandria Grandis ${ }^{1}$ Linda Chiuman ${ }^{2}$ Linda Leonando Wijaya $^{3}$ Vidya Indriani ${ }^{4}$ Gilbert Lister $^{5}$ \\ $1,2,3,4,5$ Fakultas Kedokteran Universitas Prima Indonesia \\ ${ }^{1}$ lexandriagrandis1997@gmail.com 2 linda chiuman@unprimdn.ac.id ${ }^{3}$ lindaleonando@yahoo.com
}

\begin{abstract}
Abstrak
Kunyit putih memiliki kandungan minyak atsiri. Ketombe merupakan suatu keadaan abnormal yang muncul di lapisan kulit bagian terluar dan ditandai adanya peradangan serta gatal-gatal disekitar kulit kepala. Tujuan dari penelitian tersebut untuk mengetahui efektivitas antijamur ekstrak rimpang kunyit (Curcuma zedoaria) terhadap pertumbuhan jamur Pityrosporum ovale dan Microsporum canis. Jenis penelitian adalah penelitian eksperimental laboratorium dilanjutkan Posttest Only Group Design guna mengetahui efektivitas jamur ekstrak etanol rimpang kunyit putih (Curcuma zedoaria) pada pertumbuhan jamur Pityrosporum ovale dan Microsporum canis. Penelitian ini menggunakan metode difusi cakram dengan enam perlakuan yang terdiri dari kontrol negatif (aquadest), kontrol positif untuk Pityrosporum ovale (miconazole), dan kontrol positif untuk Microsporum canis (itrakonazole) ekstrak rimpang kunyit putih konsentrasi $25 \%, 50 \%, 75 \%$, dan $100 \%$. Berdasarkan penelitian, ternyata ekstrak rimpang kunyit putih (Curcuma zedoaria) dapat menghambat pertumbuhan jamur Pityrosporum ovale dan Microsporum canis pada konsentrasi $25 \%, 50 \%$, $75 \%$ dan $100 \%$.
\end{abstract}

Kata Kunci : Ekstrak rimpang kunyit putih (Curcuma zedoaria), antijamur, Pityrosporum ovale, Microsporum canis

\begin{abstract}
Curcuma zedoaria contains essential oil. Dandruff is a condition that appears in the outer layer of the scalp and is marked by inflammation and itching around the scalp. The purpose of this study was to determine the antifungal effectiveness of Curcuma zedoaria extract on the growth of Pityrosporum ovale and Microsporum canis. This is an experimental study, Posttest Only Control Group Design, to determine the antifungal effect of Curcuma Zedoaria extract on the growth of Pityrosporum ovale and Microsporum canis. The study was completed using the disk diffusion method with six treatments consisting of negative control (aquadest), positive control for Pityrosporum ovale (miconazole), and positive control for Microsporum canis (itraconazole) Curcuma zedoaria extract with concentrations of $25 \%, 50 \%, 75 \%$, and $100 \%$. Based on research Curcuma zedoaria can inhibit the growth of Pityrosporum ovale and Microsporum canis at concentrations of $25 \%, 50 \%, 75 \%$ and $100 \%$. .
\end{abstract}

Keywords : White turmeric extract (Curcuma zedoaria), Antifungal, Pityrosporum ovale, Microsporum canis 


\section{PENDAHULUAN}

Penyakit mikroorganisme seperti bakteri, jamur, dan virus dapat menyebabkan penyakit infeksi. ${ }^{1}$ Microsporum Canis dan Pityrosporum Ovale merupakan salah satu jamur yang dapat mengakibatkan terjadinya infeksi. Penyakit infeksi harus cepat didiagnosis sehingga bisa diberikan penanganan segera.

Ketombe merupakan suatu keadaan abnormal yang muncul di lapisan kulit kepala bagian terluar dan ditandai adanya peradangan, gatal-gatal di sekitar kulit kepala, berwarna putih, kecil dan kering. Kondisi yang memperparah keadaan ketombe adalah mikroorganisme yang berlebih. Ketombe juga dikenal sebagai dandruff, seboroik kapitis, dan simpleks. ${ }^{2}$

Ketombe termasuk dermatitis seboroik, 1520\% angka kejadian dari populasi dunia. Prevalensi penderita ketombe di Indonesia berdasarkan US Sensus Bureau tahun 2004 sebanyak 43.833 .262 jiwa. $^{3}$

Ketombe sering dialami pada masa pubertas yaitu umur 20 tahun dan pada saat umur 50 tahun, gejalanya cenderung berkurang. Penyebab utama ketombe lebih sering ditemui pada laki-laki dibandingkan dengan perempuan adalah hormon androgen. ${ }^{4}$

Kunyit memiliki kandungan minyak atsiri dengan komposisi kamfen, zingiberen, sineol, borneol, dehidrokurdion, kamfor, zederon, pinen, furadienon, dan garmakon. Minyak atsiri juga memiliki senyawa kuardion yang berkhasiat sebagai antineoplastik dan sebagai hepatoprotektor dan antikanker. ${ }^{5}$

Berdasarkan penjelasan diatas, maka penulis mau meneliti tentang efektivitas antijamur ekstrak etanol rimpang kunyit putih (Curcuma Zedoaria) pada jamur Pityrosporum Ovale dan Microsporum Canis.

\section{METODE}

Metode penelitian menggunakan penelitian eksperimental laboratorium dilanjutkan Posttest Only Control Group Design guna mengetahui khasiat antijamur ekstrak etanol rimpang kunyit putih (Curcuma zedoaria) pada pertumbuhan jamur Pityrosporum Ovale dan Microsporum Canis. Penelitian ini dilakukan dari bulan September Oktober 2019 di Laboratorium Farmasi dan Toksikologi Fakultas Farmasi Universitas Sumatera Utara dan Universitas Prima Indonesia bagian Laboratorium Mikrobiologi Laboratorium.

Sampel yang digunakan seperti tanaman rimpang kunyit putih berupa serbuk simplisia kering rimpang kunyit putih yang didapatkan dari UPT Materia Medica Batu, Jawa Timur.

Alat yang digunakan adalah sarung tangan, labu takar, spuit, pinset, rak, dan tabung reaksi, alat fiksasi, tabung erlenmeyer, timbangan gram analitik, kamera, kaca petri, beaker glass, pipet mikro, autoklaf, dan alat dokumentasi.

Bahan dalam penelitian ini terdiri dari ekstrak rimpang kunyit putih (Curcuma Zedoaria) jamur Pityrosporum Ovale, jamur Microsporum Canis, etanol, aquadest, larutan DMSO, miconazole, medium Sabaroud Dextrose Agar (SDA), medium Potato Dextrose Agar (PDA)

Sterilisasi alat dan bahan yang akan dipakai menggunakan autoklaf selama 15 menit pada temperatur $121 \stackrel{\circ}{\circ}$.

Kunyit putih dicuci dan dikeringkan di lemari pengering. Setelah kering kunyit putih dihaluskan dengan menggunakan blender. Metode maserasi digunakan untuk membuat ekstrak kunyit putih dengan etanol 96\% (7,5 L). Serbuk kunyit putih dibiarkan dalam 5 hari dan terlindung dari cahaya kemudian di saring atau diserkai. Ampas kunyit putih yang sudah disaring direndam lagi dengan sisa etanol $96 \%(2,5 \mathrm{~L})$ selama 2 hari lalu disaring. Alat rotary evaporator berfungsi untuk penggabungan filtrat sampai diperoleh ekstrak hampir kental. Ekstrak tersebut diuapkan di penangas air sampai ekstrak menjadi kental.

\section{Konsentrasi Ekstrak Rimpang Kunyit Putih}

Ada berbagai konsentrasi ekstrak kunyit putih (Curcuma Zedoaria) yaitu 25\%, 50\%, 75\%, dan 100\%. Bahan yang digunakan sebagai pelarut ekstrak kunyit putih adalah aquadest.

Presentasi $=\frac{\text { zat pelarut } \text { yang digunakan }}{\text { volume larutan }} \times 100 \%$

Tabel 1: Konsentrasi ekstrak rimpang kunyit putih

\begin{tabular}{ccc}
\hline $\begin{array}{c}\text { Ekstrak } \\
\text { Kunyit Putih } \\
\text { (gr) }\end{array}$ & $\begin{array}{c}\text { Volume Akhir } \\
\text { (ml) }\end{array}$ & Konsentrasi (\%) \\
\hline 2,5 & 10 & 25 \\
\hline 5,0 & 10 & 50 \\
\hline 7,5 & 10 & 75 \\
\hline 10,0 & 10 & 100 \\
\hline
\end{tabular}

Preparasi Media

Media Sabouraud Dextrose Agar (SDA)

digunakan dalam penelitian ini.

\section{Pembuatan Media ${ }^{6}$}

1. Sabouraud Dextrose Agar, dicampur dengan aquadest di labu erlenmeyer dengan banyak 65g / 1 liter lalu dipanaskan. 
JIMKesmas

Jurnal Ilmiah Mahasiswa Kesehatan Masyarakat

Vol. 5 No.1/ Januari 2020 ; Issn 2502-73IX

2. $P D A$, larutan dimasukkan ke erlenmeyer lalu ditutup dengan kapas steril serta aluminium foil.

3. Sterilisasi alat di autoklaf dengan suhu $121^{\circ} \mathrm{C}$ dalam 15 menit.

4. Kemudian Sabouraud Dextrose Agar yang steril dimasukkan pada cawan sebanyak $20 \mathrm{ml}$, dan sterilkan lagi di dalam ruangan UV selama $1 \times 24$ jam.

\section{HASIL}

Skrining fitokimia pada ekstrak kunyit putih (Curcuma zedoaria)

Tabel 2: Hasil skrining fitokimia ekstrak kunyit putih (Curcuma zedoaria)

\begin{tabular}{cccc}
\hline No & Parameter & Hasil & Tanda \\
\hline 1 & Alkaloid & Negatif & - \\
\hline 2 & Tanin & Negatif & - \\
\hline 3 & Saponin & Negatif & - \\
\hline 4 & Triterpen/steroid & Positif & + \\
\hline 5 & Flavonoid & Positif & + \\
\hline 6 & Glikosida & Positif & + \\
\hline
\end{tabular}

Berdasarkan uji skrining fitokimia pada tabel 1, diketahui ada kandungan senyawa metabolit sekunder berupa triterpen/steroid, flavonoid dan glikosida dalam ekstrak kunyit putih (Curcuma zedoaria). Metode kualitatif digunakan untuk menguji kandungan senyawa metabolit sekunder.

Efektivitas antijamur ekstrak kunyit putih (Curcuma zedoria) terhadap jamur Pityrosporum ovale menggunakan difusi cakram ditunjukkan adanya zona hambat pada konsentrasi $25 \%, 50 \%, 75 \%$, dan $100 \%$. Gambaran zona hambat dapat dilihat pada gambar dan tabel dibawah ini.

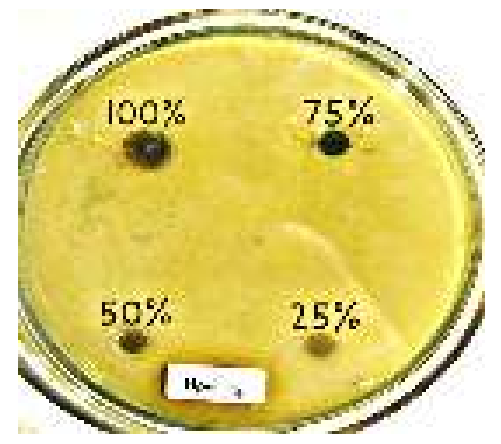

Gambar 1: Zona hambat Pityrosporum ovale Tabel 3: Zona Hambat Pityrosporum ovale
Berdasarkan tabel di atas, ekstrak etanol

\begin{tabular}{ccccc}
\hline \multirow{2}{*}{$\begin{array}{c}\text { Percobaan } \\
(\mathbf{m m})\end{array}$} & $\mathbf{2 5}$ & $\mathbf{5 0}$ & $\mathbf{7 5}$ & $\mathbf{1 0 0}$ \\
\cline { 2 - 5 } & $\mathbf{1 0 , 2}$ & 11,7 & $\mathbf{1 6 , 1}$ & 9,27 \\
\hline I & 10,2 & 11,5 & 12,2 & 10,67 \\
\hline II & 7,4 & 8,8 & 9,7 & 12,67 \\
\hline III & 9,27 & 10,67 & 10,5 & 16,07 \\
\hline Rata-rata & \multicolumn{5}{c}{27,1} \\
\hline Kontrol + & \multicolumn{5}{c}{0} \\
\hline Kontrol -
\end{tabular}

rimpang kunyit putih (Curcuma Zedoaria) konsentrasi $25 \%$ sampai dengan konsentrasi $100 \%$ terus mengalami peningkatan diameter zona hambat. Konsentrasi $100 \%$ adalah konsentrasi terbaik untuk menghambat pertumbuhan jamur sedangkan diameter zona hambat terendah adalah pada konsentrasi $25 \%$ yaitu 9,27 $\mathrm{mm}$ dan diameter zona hambat pada kontrol positif sebesar $27,1 \mathrm{~mm}$.

Efektivitas antijamur ekstrak kunyit putih (Curcuma zedoria) terhadap jamur Microsporum canis menggunakan difusi cakram ditunjukkan adanya zona hambat pada konsentrasi 25\%, 50\%, 75\%, dan $100 \%$. Gambaran zona hambat dapat dilihat pada gambar dan tabel dibawah ini.

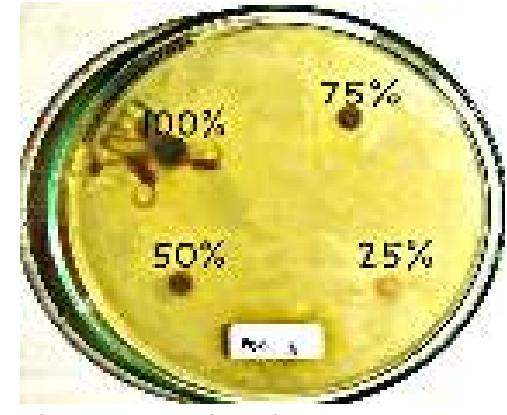

Gambar 2: Zona hambat Microsporum canis

Tabel 4: Zona hambat Microsporum canis

\begin{tabular}{ccccc}
\hline \multirow{2}{*}{$\begin{array}{c}\text { Percobaan } \\
\text { (mm) }\end{array}$} & $\mathbf{5}$ Konsentrasi(\%) \\
\cline { 2 - 5 } & $\mathbf{2 5}$ & $\mathbf{5 0}$ & $\mathbf{7 5}$ & $\mathbf{1 0 0}$ \\
\hline I & 0 & 9,44 & 10,2 & 11,6 \\
II & 12,0 & 12,7 & 13,9 & 19,9 \\
III & 7,2 & 9,1 & 10,2 & 14,2 \\
Rata-Rata & 6,40 & 10,40 & 11,43 & 15,53 \\
Kontrol + & \multicolumn{5}{c}{27,1} \\
Kontrol - & \multicolumn{5}{c}{0} \\
\hline
\end{tabular}

Berdasarkan tabel di atas, ekstrak etanol rimpang kunyit putih (Curcuma Zedoaria) konsentrasi 
$25 \%$ sampai dengan konsentrasi $100 \%$ ada peningkatan diameter zona hambat. Diameter zona hambat tertinggi adalah konsentrasi $100 \%$ yaitu 15,23 $\mathrm{mm}$ sedangkan diameter zona hambat terendah adalah pada konsentrasi $25 \%$ yaitu $6,40 \mathrm{~mm}$ dan zona hambat pada kontrol positif adalah sebesar $18,20 \mathrm{~mm}$.

\section{DISKUSI}

Berdasarkan penelitian, bahwa ekstrak kunyit putih (Curcuma zedoaria) memiliki efektivitas antijamur terhadap jamur Pityrosporum ovale dan Microsporum canis. Efektivitas antijamur ekstrak kunyit putih (Curcuma zedoaria) dibuktikan adanya zona hambat disekitar kertas cakram. Konsentrasi yang terlibat adalah 25\%, 50\%, 75\% dan $100 \%$.

Hasil tersebut menunjukkan ekstrak kunyit putih (Curcuma zedoaria) memiliki efektivitas antijamur terhadap jamur Pityrosporum ovale dengan konsentrasi $25 \%, 50 \%$, 75\%, dan $100 \%$ dengan ratarata diameter zona hambat yaitu $9,27 \mathrm{~mm}, 10,67 \mathrm{~mm}$, $12,67 \mathrm{~mm}, 16,07 \mathrm{~mm}$. Pada Microsporum canis ratarata diameter zona hambat yaitu $6,40 \mathrm{~mm}, 10,40 \mathrm{~mm}$, 11,43 mm, 15,23 mm. Aktivitas jamur ekstrak kunyit putih (Curcuma zedoaria) terhadap jamur Pityrosporum ovale dan Microsporum canis pada konsentrasi $25 \%$, 50\%, 75\%, dan $100 \%$ tergolong dalam kategori bisa menghambat pertumbuhan jamur Pityrosporum ovale dan Microsporum canis, sedangkan pada kontrol positif yang menggunakan miconazole terdapat efektivitas yang kuat dalam menghambat pertumbuhan jamur Pityrosporum ovale dengan rata-rata diameter zona hambat yaitu 27,1 $\mathrm{mm}$, untuk kontrol negatif tidak menunjukkan zona hambat pada bakteri Pityrosporum ovale. Pada jamur Microsporum canis yang menggunakan itrakonazole memiliki zona hambat yaitu $18,2 \mathrm{~mm}$ untuk kontrol positif dan tidak memiliki zona hambat pada kontrol negatif.

Microsporum canis memiliki dinding sel tebal dan kasar serta fase yang lambat. Dinding sel jamur terdiri dari lapisan multipel (mannoprotein dan glukan $80 \%$ serta kitin 2\%). Mannoprotein secara predominan mengekspresikan permukaan eksternal. ${ }^{7}$ Susunan utama membran plasma Microsporum canis dan Ptyrosporum ovale adalah ergosterol. Ergosterol memiliki peranan penting pada pertahanan sel jamur. Peran ergosterol adalah biosintesis, pengambilan dan pelepasan bahan, menghasilkan rangkaian karbohidrat, penyalur sinyal dari lingkungan, serta sebagai tempat penyimpanan enzim dinding sel. Faktor ini mempengaruhi seberapa efektif permeabilitas obat kedalam sel jamur, semakin tebal dinding sel semakin sulit suatu senyawa masuk ke dalam sel. ${ }^{8}$

Pityrosporum ovale memiliki peptidoglikan pada struktur dinding sel, sedikit lemak serta mengandung asam teikoat. Keluar masuknya ion positif diatur oleh asam teikoat. ${ }^{9}$

Hasil skrining fitokimia menunjukkan ekstrak kunyit putih (Curcuma zedoaria) mengandung senyawa triterpen atau steroid, flavonoid, dan glikosida.

Terpenoid termasuk senyawa bioaktif yang berfungsi sebagai antijamur. Hal tersebut dapat menghambat pertumbuhan jamur melalui membran sitoplasma. ${ }^{10}$

Kerja flavonoid yaitu mendenaturasi dan koagulasi protein sel jamur Pityrosporum ovale dan Microsporum canis dengan menginduksi kebocoran membran. Akibatnya, terjadi lisis membran dan elektrokimia yang penting bagi kehidupan sel. ${ }^{11}$

Flavonoid dapat berperan sebagai anti jamur dengan dua mekanisme yaitu mekanisme pertama dapat mengganggu pembentukan membran sel jamur melalui inhibisi biosintesis ergosterol sedangkan mekanisme kedua dapat menganggu homeostasis mitokondria sel jamur melalui penurunan potensial membran mitokondria serta inhibisi pompa ion pada proses metabolime sel jamur sehingga mengakibatkan turunnya produksi ATP pada sel jamur. ${ }^{12}$

\section{SIMPULAN}

Berdasarkan penelitian yang dilakukan terbukti bahwa ekstrak kunyit putih (Curcuma zedoaria) pada konsentrasi $100 \%$ memiliki efektivitas sebagai antijamur dalam menghambat pertumbuhan jamur Pityrosporum ovale dan Microsporum canis.

\section{SARAN}

1. Penelitian ini perlu diperdalam lagi guna melihat keefektivitasan daya hambat rimpang kunyit putih (Curcuma zedoaria) terhadap jamur lain dengan konsentrasi yang berbeda.

2. Penelitian secara in vivo perlu dilakukan guna membuktikan efek antijamur ekstrak rimpang kunyit putih (Curcuma zedoaria) menjadi obat alternatif di bidang kesehatan bagi masyarakat luas.

\section{DAFTAR PUSTAKA}

1. DE Rahmanto. Bab 1 Pendahuluan (Latar Belakang Periklanan). 2014;12 
2. Ii BAB. Formulasi Shampo Antiketombe, Sri Yuniati, Fakultas Farmasi UMP, 2013. 2013;4-15.

3. li BAB, Pustaka T. berasal dari bahasa Anglo-saxon kombinasi dari. :7-23.

4. Setyowati H, Hanifah HZ, Nugraheni RP. Krim kulit buah durian (Durio zibethinus I.) Sebagai obat herbal pengobatan infeksi jamur candida albicans. Media Farm Indones [Internet]. 2013;8(2):1-7. Available from: http://artikel.dikti.go.id/index.php/PKM$\mathrm{P} /$ article/view/40

5. Putih K, Mangga C, Beberapa D, Di D. Komposisi Minyak Atsiri Rimpang ( Curcuma Mango Val .) From Some Regions. 2013;9(1).

6. Iv BAB, Penelitian M. Saboouraud Dextrose Agar. 2017;32-41.

7. Curcuma K, Terhadap DL, Albicans C, Plat P, Akrilik $\mathrm{R}, \mathrm{Nxq} \mathrm{H}$, et al. Efektivitas ekstrak lengkuas putih (. 2:37-41.

8. Saefudin, Syarif F, Chairul. Antioxidant Potential and Proliferative Activity of Curcuma Zedoaria Rosc. Extract oh Hela Cells. Widyariset [Internet]. 2014;17(3):381. Available from: http://www.widyariset.pusbindiklat.lipi.go.id/inde x.php/widyariset/article/view/282

9. Septiani S, Dewi EN, Wijayanti I. Aktivitas Antibakteri Ekstrak Lamun (Cymodocea rotundata) Terhadap Bakteri Staphylococcus aureus DAN Escherichia coli (Antibacterial Activities of Seagrass Extracts (Cymodocea rotundata) Against Staphylococcus aureus and Escherichia coli). SAINTEK Perikan Indones J Fish Sci Technol. 2017;13(1):1.

10. Lutfiyanti R, Ma'ruf WF, Dewi EN. Aktivitas Antijamur Senyawa Bioaktif Ekstrak Gelidium latifolium TERHADAP Candida albicans. J Pengolah dan Bioteknol Has Perikan. 2012;1(1):26-33.

11. Nadifah F, Farida Muhajir N, Retnoningsih F. Daya Hambat Minyak Atsiri Rimpang Kunyit terhadap Pertumbuhan Candida Albicans In Vitro. J Vokasi Kesehat. 2018;4(1):1.

12. Maryanti E, Febriyani E, Lestari E. Studi Efektivitas Antijamur Nanopartikel ZnO / ZnS Terhadap Pertumbuhan Jamur Pityrosporum ovale Penyebab Ketombe. 2014;10(2):1014-7. 